\title{
入院を要した鼻出血症例の検討
}

\author{
日高 利美・山本 英一 $*$ ・秋定 健 $\cdot$ 半田 徹 \\ 河合 晃充・東川 康彦・折田 洋造
}

\section{Clinical Study of Hospitalized Patients with Severe Epistaxis}

\author{
Toshimi Hidaka, Takeshi Akisada, Toru Handa, Akimitsu Kawai, \\ Yasuhiko Higashikawa and Yozo Orita
}

(Kawasaki Medical School)

Hidekazu Yamamoto

(Kawasaki Hospital, Kawasaki Medical School)

\begin{abstract}
One hundred patients with epistaxis requiring hospitalization during the past fifteen years were analyzed statistically. Epistaxis was observed more frequently in males (66) than in females (34) and occurred more frequently in May. The bleeding site was more often observed in other than the Kiesselbach's area. The patients exhibited complications due to some systemic diseases, especially hypertension. Almost all cases were treated with conservative balloon tamponade therapies and 38 cases underwent surgery.
\end{abstract}

Key words: epistaxis, hypertension, balloon tamponade

\section{はじめに}

鼻出血は耳鼻咽喉科の日常診療に括いて, 遭 遇する頻度の高い疾患である. その大半は，比 較的短時間で容易に止血しらるが，中には止血 が困難で入院治療を余儀なくされる例も少なく ない，今回，過去15年間に鼻出血で当科を受診 し，入院治療を要した患者の統計的観察を行っ たので，その結果を報告する．

\section{対 象}

昭和 53 年 1 月より平成 4 年 12 月までの 15 年間 に当科に执いて入院を要した鼻出血症例 100 例 である.鼻副鼻腔手術後出血例と, 悪性腫瘍に よる鼻出血例は除外した。

\section{結果}

1 男女差と年路分布 100例中，男性66例 (66.0\%) 女性34例 (34.0 \%)で男性に多かった。年齢分布は図 1 のごと く, 30〜 70歳代の男性に多く, 男性では50歳代 にピークがあり，女性では，60歳代にピークが あった。

\section{2 発症時期}

初回発症時期は，1月〜 7 月，特に 5 月に発 症頻度が高く，8月〜12月までは10月を除いて 低い傾向が認められた(図 2 )。

3 初回出血部位

鼻出血の好発部位は, 出血部位のはっきりし 
たキーゼルバッ八部位からのものは 35 例 (35.0 \%)であり, 下鼻甲介 6 例 $(6.0 \%)$, 中鼻道 5 例 $(5.0 \%)$ の順で出血点不明例のものは54例 ( 54.0 \%)と多いのが特徵的であった(表 1).

\section{4 合併症}

合併症は, 中〜高齢者の入院患者が多かった こともあり, 高血圧症の頻度が42例 (42.0\%) と 高く, 鼻出血のみならず血圧のコントロールも 必要となった症例が多かった。 鼻疾患では, 慢 性副鼻腔炎, アレルギー性鼻炎の合併が多かっ た(表 2 ).

\section{5 治 療}

入院中に行われた処置については, 表 3 のご とく, 全身的治療のうち止血剤の投与は, 静注 - 内服とも全例飞行われて扣り, 輸血は 8 例 (8.0\%)に行われて打り，2 例は来院時, すで に出血性ショックを来し, 輸血の適応があった.

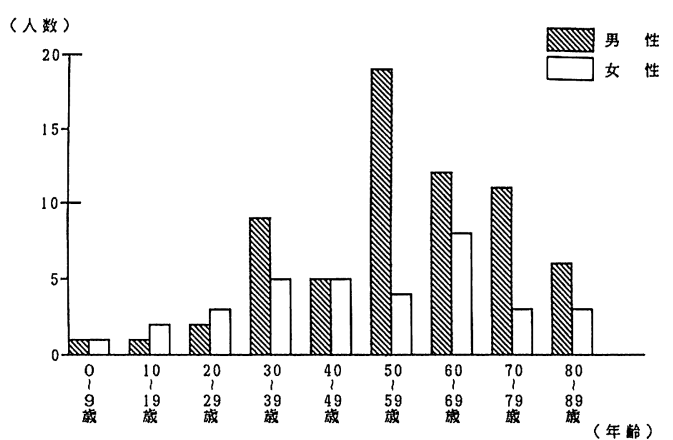

図1男女差と年齢分布

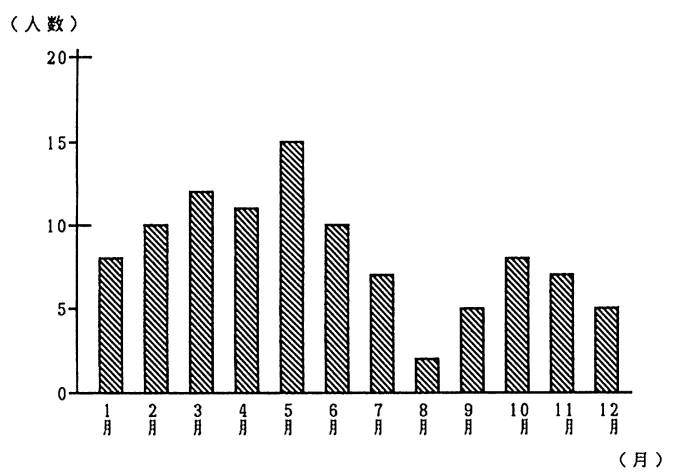

図 2 発症時期(初回発症時期)
局所的治療のらち, 従来のベロックタンポンの 代用などバルーンタンポンは53例(53.0\%)で最 も多く行われ，次にガーゼタンポン45例(45.0 $\%$ ，電気凝固33例(33.0\%)であった。バルー ンタンポン使用時にタンポンガーゼを挿入する かわりに，フイブリン糊を使用したものは，15 例(15.0\%)であり, 高血圧症や, 肝疾患, 血液 疾患などの基礎疾患があり, 難治性の鼻出血例 に試みられていた。顎動脈結杽術は，7 例(7.0 $\%)$ ，前箳骨動脈結紮術は，18例(18.0\%)，動 脈塞栓術は，2 例(2.0\%)に行われており，バ ルーンタンポンで止血し難い, 反復する鼻出血 例に行われていた. 血液疾患のらちオスラー病 の 2 例は, 1 例が当科入院, 1 例は他科入院で 止血処置を行った例であるが，表 3 に示した全 身的治療, 局所的治療の汪とんど全ての処置が

表 1 初回出血部位

（＊重複例は各々の部位で 1 例ずつとした.）

\begin{tabular}{lr}
\hline \hline 1. 不 明 & 54 例 $(54.0 \%)$ \\
2. キーゼルバッ八部位 & 35 例 $(35.0 \%)$ \\
3. 下鼻甲介 & 6 例 $(6.0 \%)$ \\
4. 中 鼻 道 & 5 例 $(5.0 \%)$ \\
5. 中鼻甲介 & 3 例 $(3.0 \%)$ \\
6. 鼻 腔 底 & 3 例 $(3.0 \%)$ \\
7. キーゼルバッ八部位以外の & 2 例 $(2.0 \%)$ \\
8. 鼻中隔 & 1 例 $(1.0 \%)$ \\
\hline 鼻 道 &
\end{tabular}

表 2 合併症

\begin{tabular}{|c|c|}
\hline \multicolumn{2}{|l|}{ 耳鼻科的疾患（例） } \\
\hline 1. 慢性副鼻腔炎 & 7 例 $(7.0 \%)$ \\
\hline 2. アレルギー性鼻炎 & 6 例 $(6.0 \%)$ \\
\hline 3. 鼻中隔弯曲症 & 4 例 ( $4.0 \%)$ \\
\hline 4.鼻ポリープ & 1 例 ( $1.0 \%)$ \\
\hline \multicolumn{2}{|l|}{ 耳鼻科以外の疾患（例） } \\
\hline 1. 高血圧症 & 42例 $(42.0 \%)$ \\
\hline 2. 肝 疾 患 & 11例 $(11.0 \%)$ \\
\hline 3. 血液疾患 & 6 例 $(6.0 \%)$ \\
\hline 4. 糖尿病 & 5 例 $(5.0 \%)$ \\
\hline
\end{tabular}


行われていた.

6 処置後経過

入院処置後の経過は, 全例が止血剤の投与を され，退院 1 週間後に外来で経過観察されてい る. 初回入院で止血し得た例は78例(78.0\%)で, 出血を繰り返し再入院となった例は22例(22.0 \%)であった。このうち18例(18.0\%)は鼻疾患, 全身的疾患などの基礎疾患があり，いずれも止 血処置と併せて基礎疾患の治療も行っていた.

考察

当科に拈ける15年間の臨床統計の結果を併せ て文献的に考察すると，男女差に関しては，男 性が多く, これは他の報告12) に一致しておう， 男性の場合仕事によるストレスや飲酒の機会, 契煙などとの関係が推察される．年齢分布に関 しては，中〜高㱓者に多かったが，佐々木ら は，入院を要する鼻出血は，特に高齢者に多い ことから, 動脈硬化症は, 男性に多くそれに密 接に関係する高血圧症も，男性に多いと報告し ている.

発症時期に関しては，入院を要する鼻出血に ついての本邦の統計では, 春から夏にかけての
発症が多いとする報告4) と，冬期に多いとする 報告1)がある。佐々木らは鼻出血と気象の関係 をあげ，湿度の低下，低気圧の接近，寒冷前線 の通過に一致して, 鼻出血の発症が増加すると 報告している. 当科では，1月〜 7 月と冬から 夏にかけて多かった。 これは佐々木らの報告に よる気象因子の関連や，アレルギー性鼻炎の関 与などが考えられる。

出血部位に関しては, 鼻出血の好発部位とい われる，キーゼルバッ八部位からのものは35例 であり, 不明のものを含めたキーゼルバッ八部 位以外からのものは74例であった。（症例100例 中, 重複例は, 各々の部位で 1 例ずつとした). これは, 入院を要するよらな難治性の鼻出血は, キーゼルバッ八部位以外からのものが多いとい う他の報告1225) 飞一致している。また，難治性 の鼻出血例で，出血を繰り返した血液疾患のオ スラー病の場合は, 出血部位がキーゼルバッハ 部位だけでなく，鼻粘膜全体に末梢血管拡張を 認め, わずかの刺激で出血が起こり, 止血処置 をしても他の場所に血管拡張部が出現し, 再出 血が認められ，難治性であった。

表 3 入院中の治療 (重複例を含む)

\begin{tabular}{|c|c|}
\hline \multicolumn{2}{|l|}{ 全身的治療 } \\
\hline 1. 止血剂投与(静注, 内服) & 100 例 $(100.0 \%)$ \\
\hline 2 . 輸血 & 8 例（ $8.0 \% ）$ \\
\hline \multicolumn{2}{|l|}{ 保存的治療 } \\
\hline 1. バルーンタンポン & 53例（ $53.0 \%)$ \\
\hline 2.ガーゼタンポン & 45例（ $45.0 \%)$ \\
\hline 3．電気凝固 & 33 例（33.0\%） \\
\hline 4.フィブリン糊 & 15例（15.0\%） \\
\hline 5.オキシセル, スポンゼル & 11例（11.0\%） \\
\hline 6 . 腐蝕 & 10例（10.0\%) \\
\hline \multicolumn{2}{|l|}{ 外科的治療 } \\
\hline 1．動脈結紮 一靧動脈結禁 & 7 例 ( $7.0 \%)$ \\
\hline L 前穊骨動脈結紮 & 18例（18.0\%) \\
\hline 2. 皮膚移植 & 5 例 ( $5.0 \%)$ \\
\hline 3.クライオサージェリー & 4 例 ( $4.0 \%)$ \\
\hline 4. 動脈塞栓, 靧動脈塞栓 & 2 例 ( $2.0 \%)$ \\
\hline 5.レーザー & 2 例 ( $2.0 \%)$ \\
\hline
\end{tabular}


合併症に関しては，当科では全身的疾患のう ちの高血圧症を伴ら例が42例 (42.0\%) と多く, 他の報告6) とほぼ一致した，鼻出血患者の場合， 来院時流出する血液のため興奮状態となり，そ の結果，血圧の高值を示すことは稀ではないが, 止血処置後も高血圧の治療を必要とする症例が 多かった。続いて, 肝疾患, オスラー病を含む 血液疾患であった：これらの合併症は，中～高 齢者の鼻出血例に多く，年路的な動脈硬化や末 梢血管収縮による血圧の上昇, またこの世代で は, 出血時間や凝固機能に影響のある基礎疾患 を合併することが多いと思われる，鼻疾患とし ては, 慢性副鼻腔炎・アレルギー性鼻炎・鼻中 隔わん曲症などが多かった，堀口7)は，これら 炎症性鼻出血と鼻咽頭炎との合併を報告してい る. 止血処置と同時に鼻出血の発症に関係する 基礎的鼻疾患の存在を常に考慮することは, 重 要である.

治療に関しては, 全身的治療として全例に止 血剂の投与が行われており，必要に応じて輸血 が行われていた. 特に血液疾患のオスラー病の 一例は, 出血性ショックを来しやすく, 輸血を 必要とした。

局所的治療としての止血法は，原則として圧 迫止血法であるが，当科では，硝酸銀の腐蝕や， オキシセル，電気凝固による止血が行われてお り, タンポンガーゼによる圧迫固定や，バルー ンカテーテルを挿入し，タンポンガーゼで圧迫 するバルーンタンポン止血法が行われている.

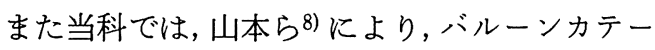
テル挿入後, 鼻腔内にタンポンガーゼを挿入す るかわりに，フィブリン糊を充満させ，タンポ ンガーゼ挿入以上の止血効果を得たといら報告 をして括り, オスラ一病を含む, 難治性鼻出血 例で行われていた。 しかしながら出血部位が広 範囲であったり, 深部に認められる場合や，拍 動性である場合などは，これらの処置に加えて， 買動脈結紮術, 前篩骨動脈結禁術, 動脈塞栓術 が行われている ${ }^{9)}$. 難治性の鼻出血例であるオ スラー病の場合は, さらにクライオサージェ
リー, レーザー手術, 鼻粘膜剝離, 皮膚移植, また，全身的にェストロゲンの投与などの種々 の止血法が施行され，止血効果を得ている.才 スラー病 (Osler-Rendou-Weber 病) は, 遺伝性 出血性末梢血管拡張症といわれ, 血管拡張部の 鼻粘膜を凝固，または切除したとしても，新た な血管拡張部が生じ，再出血し，上記のような 種々の止血処置が試みられる. 当科に扮けるオ スラー病の一症例は，上記の止血法が行われる も難治性で, 再出血を繰り返し, 17回の入院と 止血処置が行われていた.

処置後の経過に関しては, ほぼ全例が退院後 も止血剂を内服し， 1 週間以内に外来にて経過 観察されて扣り，入院時に基礎疾患が発見され た症例は, 退院後も, 当院もしくは近医にて, 基礎疾患の治療が行われていた。特に，合併症 の中でも最も多かった高血圧症の症例は, 当院 もしくは近医内科にて経過観察されていた。止 血処置後の局所の経過観察も大切であるが，鼻 出血の発症に関する基礎疾患の検索扤よび治療 も重要であると思われる.

\section{まとめ}

1) 昭和53年 1 月より平成 4 年12月までに入 院を要した鼻出血症例100例について検討した.

2 ）男性は，66例 (66.0\%)女性は，34例(34.0 \%)で，男性は，50歳代に，女性は60歳代に多 い傾向があった.

3 ) 発症時期としては，1月〜 7 月，特に 5 月に多い傾向が認められた。

4 ）出血部位としては，出血不明例が多かっ た. 次いでキーゼルバッ八部位であった。

5 ) 合併症としては，耳鼻科的疾患では，慢 性副鼻腔炎, アレルギー性鼻炎が多く, 耳鼻科 以外の疾患では, 高血圧症, 肝疾患が多かった.

6 ）鼻出血の治療は止血処置も大切であるが, 鼻出血の発症に関係する基礎的疾患の存在を常 に考慮することが重要である. 


\section{参考文献}

1）小林加代子, 吉川兼人：入院を要した鼻出血症 例の検討. 耳鼻臨床 補 $16: 87 \sim 91,1987$.

2）井上裕章, 朝隅真一郎 : 入院を要した鼻出血例. 耳鼻 $28: 382 \sim 386,1982$.

3）佐々木修, 伊藤和也：入院治療を要した鼻出血 例の統計的観察.耳鼻臨床 補38:82 87, 1990.

4) 山本 肇, 弘兼倫彦: 日常よくみられる鼻出血 とその処置. 耳鼻 補26:745〜 753, 1980.

5）新川秀一，綿貫幸三 : 入院を必要とした鼻出血 患者の統計的観察. 耳鼻 $25: 181 \sim 186,1979$.

6) 石井正則,鶴岡美果 : 鼻出血の統計. 耳展 35 :
45〜 51, 1992.

7）堀口伸作 : 鼻出血の治療. 耳喉 $54: 1017 \sim 1022$, 1982.

8）山本英一, 折田洋造 : 鼻出血に対するフィブリ ン糊を用いた止血方法. 耳喉 $56: 167 \sim 170$, 1984.

9）山本英一, 折田洋造 : 鼻出血に対する顎動脈結 禁術. 救急医学 $7: 1025 \sim 1029,1983$.

$$
\left(\begin{array}{l}
\text { 別刷請求先 : 日高利美 } \\
\text { 干701-01 倉敷市松島 } 577 \\
\text { 川崎医科大学耳鼻咽喉科学教室 }
\end{array}\right)
$$

